\title{
Weighted Gene Co-Expression Network Coupled with a Critical-Time-Point Analysis during Pathogenesis for Predicting the Molecular Mechanism Underlying Blast Resistance in Rice
}

\author{
Dagang Tian ${ }^{1,2^{*}}\left(\mathbb{D}\right.$, Zaijie Chen ${ }^{1}$, Yan Lin ${ }^{1}$, Ziqiang Chen ${ }^{1}$, Khuynh The Bui ${ }^{3}$, Zonghua Wang ${ }^{2^{*}}$ and Feng Wang ${ }^{1 *}$
}

\begin{abstract}
Background: Rice blast, caused by the ascomycete fungus $M$. oryzae, is one of the most important diseases of rice. Although many blast resistance $(R)$ genes have been identified and deployed in rice varieties, the molecular mechanisms responsible for the $R$ gene-mediated defense responses are yet not fully understood.

Results: In this study, we used comparative transcriptomic analysis to explore the molecular mechanism involved in Piz-t-mediated resistance in a transgenic line containing Piz-t (NPB-Piz-t) compared to Nipponbare (NPB). Clustering and principal component analysis (PCA) revealed that the time-point at 24-h post inoculation (hpi) was the most important factor distinguishing the four time-points, which consisted of four genes of mitogen-activated protein kinases (MAPKs) signaling pathway, one gene related to WRKY DNA-binding domain containing protein, five pathogenesis-related protein (OsPR1s) genes, and three genes of $R$ proteins involving in the most significant protein-protein interaction (PPI) pathway. Using weighted gene co-expression network analysis (WGCNA) to investigate RNA-seq data across $0,24,48$, and $72 \mathrm{hpi}$, nine modules with similar patterns expression pattern (SEP) and three modules with differential expression pattern (DEP) between NPB-Piz-t and NPB across 0, 24, 48, and 72 hpi with KJ201 (referred to as Piz-t-KJ201 and NPB-KJ201) were identified. Among these the most representative SEP green-yellow module is associated with photosynthesis, and DEP pink module comprised of two specific expressed nucleotide-binding domain and leucine-rich repeat (NLR) genes of LOC_Os06g17900 and LOC_Os06g17920 of Pi2/9 homologous, three NLR genes of LOC_Os11g11810, LOC_Os11g11770, and LOC_Os11g11920 which are putatively associated with important agronomic traits, and a B3 DNA binding domain containing protein related genes (LOC_ Os10g39190). Knockout of LOC_Os10g39190 via CRISPR-Cas9 resulted in plant death at the seedling stage.
\end{abstract}

(Continued on next page)

\footnotetext{
*Correspondence: tdg@fjage.org; wangzh@fafu.edu.cn; wf@fjage.org

'Biotechnology Research Institute, Fujian Provincial Key Laboratory of Genetic

Engineering for Agriculture, Fujian Academy of Agricultural Sciences, Fuzhou 350003, China

${ }^{2}$ State Key Laboratory of Ecological Pest Control for Fujian and Taiwan Crops, College of Life Science, Fujian Agriculture and Forestry University, Fuzhou,

China

Full list of author information is available at the end of the article
}

\section{Springer Open}

( ) The Author(s). 2020 Open Access This article is licensed under a Creative Commons Attribution 4.0 International License, which permits use, sharing, adaptation, distribution and reproduction in any medium or format, as long as you give appropriate credit to the original author(s) and the source, provide a link to the Creative Commons licence, and indicate if changes were made. The images or other third party material in this article are included in the article's Creative Commons licence, unless indicated otherwise in a credit line to the material. If material is not included in the article's Creative Commons licence and your intended use is not permitted by statutory regulation or exceeds the permitted use, you will need to obtain permission directly from the copyright holder. To view a copy of this licence, visit http://creativecommons.org/licenses/by/4.0/. 
(Continued from previous page)

Conclusions: The research suggested that Piz-t and multiple NLR network might play important roles in the regulation of the resistance response in the Piz-t-KJ201 interaction system. The identified genes provide an NLR repository to study the rice- $M$. oryzae interaction system and facilitate the breeding of blast-resistant cultivars in the future.

Keywords: Rice, Blast, RNA-seq, Piz-t, Clustering, PCA, WGCNA

\section{Background}

Rice blast is a major disease threatening global rice production, causing a $10-30 \%$ global crop yield losses. Utilization of rice-blast resistant cultivar is the most economical and environment-friendly way of minimizing crop losses. Currently, over 100 rice-blast $R$ genes have been mapped and at least 32 have been characterized and cloned (Xiao et al. 2020; Zhao et al. 2018). However, only few broad-spectrum and durable resistant cultivars have been bred due to the highly complex and dynamic process associated with blast resistance response (Ashkani et al. 2016).

The completion of the whole genome sequences for rice and $M$. oryzae has made the pathosystem become a premier model for studying plant-fungal interactions, which increases our understanding of the mechanisms underlying fungal infections. The major members involved in rice- $M$. oryzae interactions include pattern-recognition receptors (PRRs) and NLR genes from rice, which trigger a diverse array of immune responses including energy metabolism, pathogen recognition, defense related proteins, hormone signaling, ROS, and redox homeostasis, especially on the changes of genes expression and transcriptional reprogramming. Of these, $R$ genes are well studied as the famous gene for gene resistance; meanwhile, a large NLR proteins immune signaling network responses to invading pathogens and confers more durable resistance than single race-specific $R$ gene (Wu et al. 2017). Understanding of these genes mediated defense response to blast can be useful in helping resistance breeding.

Previously, proteome and transcriptome analyses have revealed many genes involving in the defense responses of rice to M. oryzae (Wei et al. 2013; Wang et al. 2014; Zhang et al. 2016; Jain et al. 2017; Tian et al. 2018), however, little is known about the potential connection among these genes. Recently, several approaches have been developed to look at genes with similar expression patterns which may participate in specific biological functions. One approach is the method named WGCNA, which was implemented as a $R$ package to identify significant associated genes modules with similar expressions. This reduces the dimension of complex data and simplifies it into several modules, thereby providing an overview of gene-gene inter-relationships at the system level. In addition, clustering is a useful exploratory technique for analysis of gene expression data, and PCA can help to reduce the dimensionality of the data set by transforming to a new set of variables to summarize the features of the data. Thus, integrating these two analysis techniques to analyze the four time-point data can contribute to determine the critical one (Yeung and Ruzzo 2001).

The rice blast $R$ gene Piz- $t$ is a member of the Pi2/9 multi-allelic gene family on chromosome $6(\mathrm{Qu}$ et al. 2006), which follows a gene-for-gene fashion to the $M$. oryzae AVR gene AvrPiz-t (Li et al. 2009a, b). This gene was once widely used in breeding programs for increasing resistance to $M$. oryzae (Zhou et al. 2006; Tian et al. 2020). Numerous studies also have examined the interaction profiles of Piz-t-AvrPiz-t in rice (Park et al. 2012, 2016; Wang et al. 2016; Tang et al. 2017; Tian et al. 2018; Bai et al. 2019; Zhang et al. 2020). However, transcriptome profiling underlying the Piz-t-mediated rice resistance to blast fungus remains largely unknown.

Generally, the whole infection process begins at the first time infected at $24 \mathrm{hpi}$, and then invades the neighboring cells at $48 \mathrm{hpi}$ (Cao et al. 2016). Subsequently, rice blast disease lesions will emerge about 72 hpi (Wilson and Talbot 2009). The objective of this study then is to identify a set of candidate defense genes mediated by Piz- $t$ with $M$. oryzae using the clustering, PCA, and WGCNA approach across the four time-points. Notably, a larger number of $R$ genes and regulators were identified during pathogenesis. The identified genes can be further studied to reveal the molecular mechanisms underlying rice-blast interactions in the future.

\section{Results \\ RNA-Seq and Validation of RNA-Seq Data by qRT-PCR}

Leaf tissues were collected from each rice line at 0, 24, 48, and 72 hpi for RNA-seq. Some plants were retained for investigation of disease progression. There were some spindle-shaped lesions on NPB leaves and no obvious disease phenotype on Piz-t-KJ201 leaves after 7 days of incubation according to a disease rating of 5 (on a 05 scale) (Mackill and Bonman 1992) (Fig. 1a). RNA-Seq analysis of Piz-t-KJ201 and NPB-KJ201 were conducted as shown in Fig. 1b. A total of 1,242,379,052 high-quality reads were generated, and over $90 \%$ of the reads in each sample successfully aligned to RGAP7, with unique mapped reads at $>85 \%$, and multiple mapped reads or fragments were $<6 \%$. To confirm the gene expression 


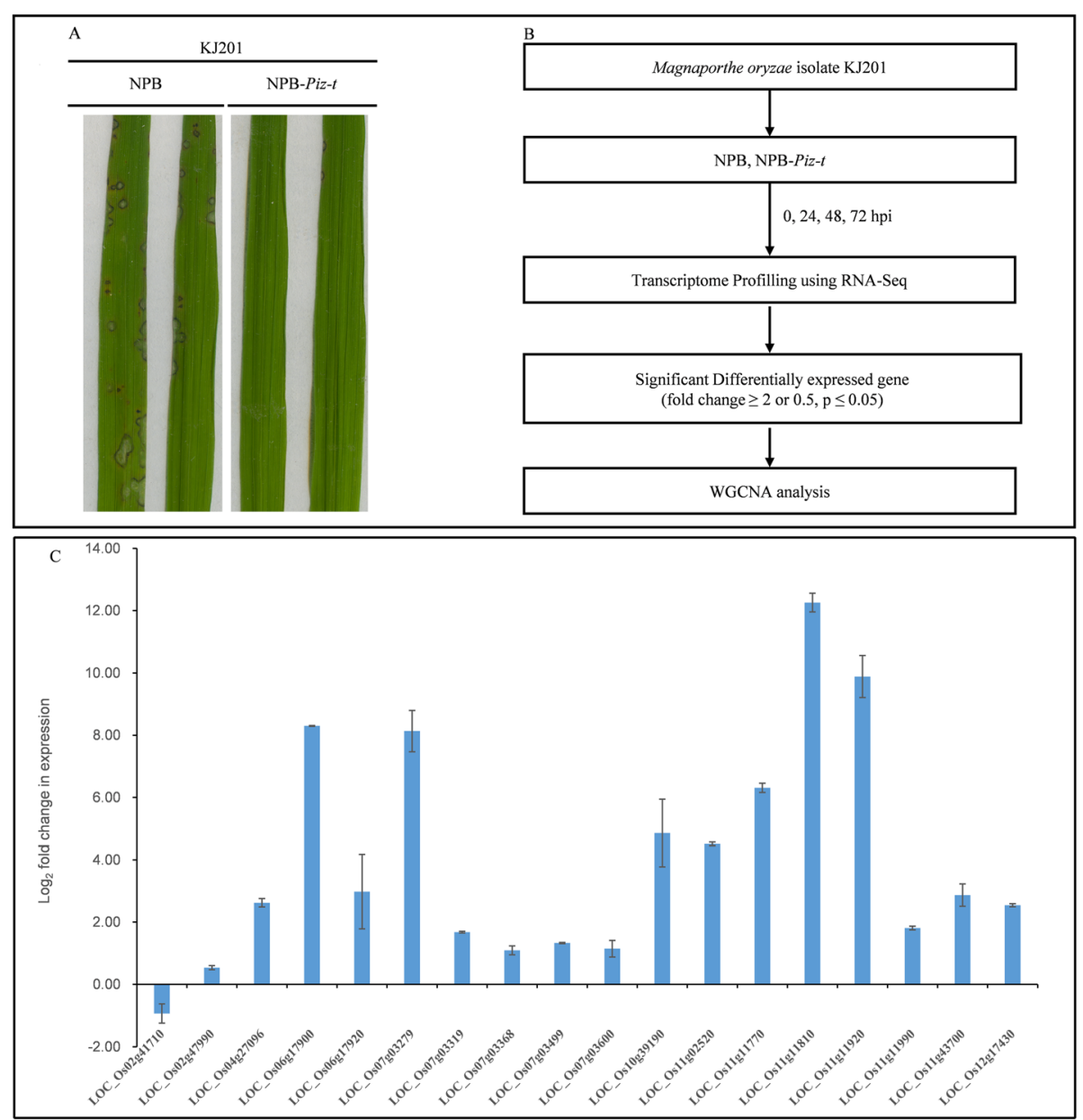

Fig. 1 Disease phenotype of NPB and NPB-Piz-t inoculated with KJ201 and the workflow of the transcriptomic experiment and validation for WGCNA. a Phenotype of NPB and NPB-Piz-t inoculated with KJ201. b The workflow for leaf transcriptome of Piz-t-KJ201 and NPB-KJ201 using RNA-Seq. $\mathbf{c}$ The qRT-PCR validation of the differentially expressed gene between NPB-Piz-t and NPB inoculated with KJ201 in the PPI pathway at 24 hpi. The data were log2 transformed for FC

patterns identified from the RNA-seq data, the transcript levels of 18 important genes were examined and validated by qRT-PCR (Additional Table 1). All the gene expression patterns obtained were found in consistency with the RNA-seq data (Fig. 1c).

Results from the venn diagram showed that the upregulated differentially expressed genes (DEGs) were $406,175,98$, and 104, and the down-regulated ones with $50,71,33$, and 280 at $0,24,48$, and $72 \mathrm{hpi}$, respectively, and 49 common DEGs at the four time-points (Fig. 2a, b). Clustering analysis also revealed that those DEGs at the four time-points have consistent expression levels among their three replicates, respectively. Although part of those genes expression levels at Piz-t-Ohpi.3 were different with that at Piz-t-0hpi.1 and Piz-t-0hpi.2, they had higher level of consistency with Piz-t-0 hpi compared with NPB-0 hpi (Additional Fig. 1.A, B, C, D). Further comparisons of the DEGs across the four time- points showed that most of the DEGs were up-regulated at $0 \mathrm{hpi}$ and down-regulated at $24 \mathrm{hpi}$. In contrast, almost opposite expression patterns were seen between 0 and 24 hpi. Also, the DEGs at 24 hpi were significantly different from the other three time-points as shown by Fig. 2c. PCA on 24 group data related to Piz-t-KJ201 and NPB-KJ201 with three replicates revealed that the first principal component ( $\mathrm{PC}$ ), $\mathrm{PC} 1$, provided the most information on time-points that determine expression difference (Fig. 3), suggesting that the time-point at 24 hpi is the most significant factor that triggers global defense response in gene expression.

Previous studies suggested that the pathogens finish the first time infected at $24 \mathrm{hpi}$, accordingly, the rice activates defense responses against $M$. oryzae before $24 \mathrm{~h}$ (Bagnaresi et al. 2012; Jain et al. 2017). Thus, this timepoint at $24 \mathrm{hpi}$ is the most intriguing for further extensive exploration. 


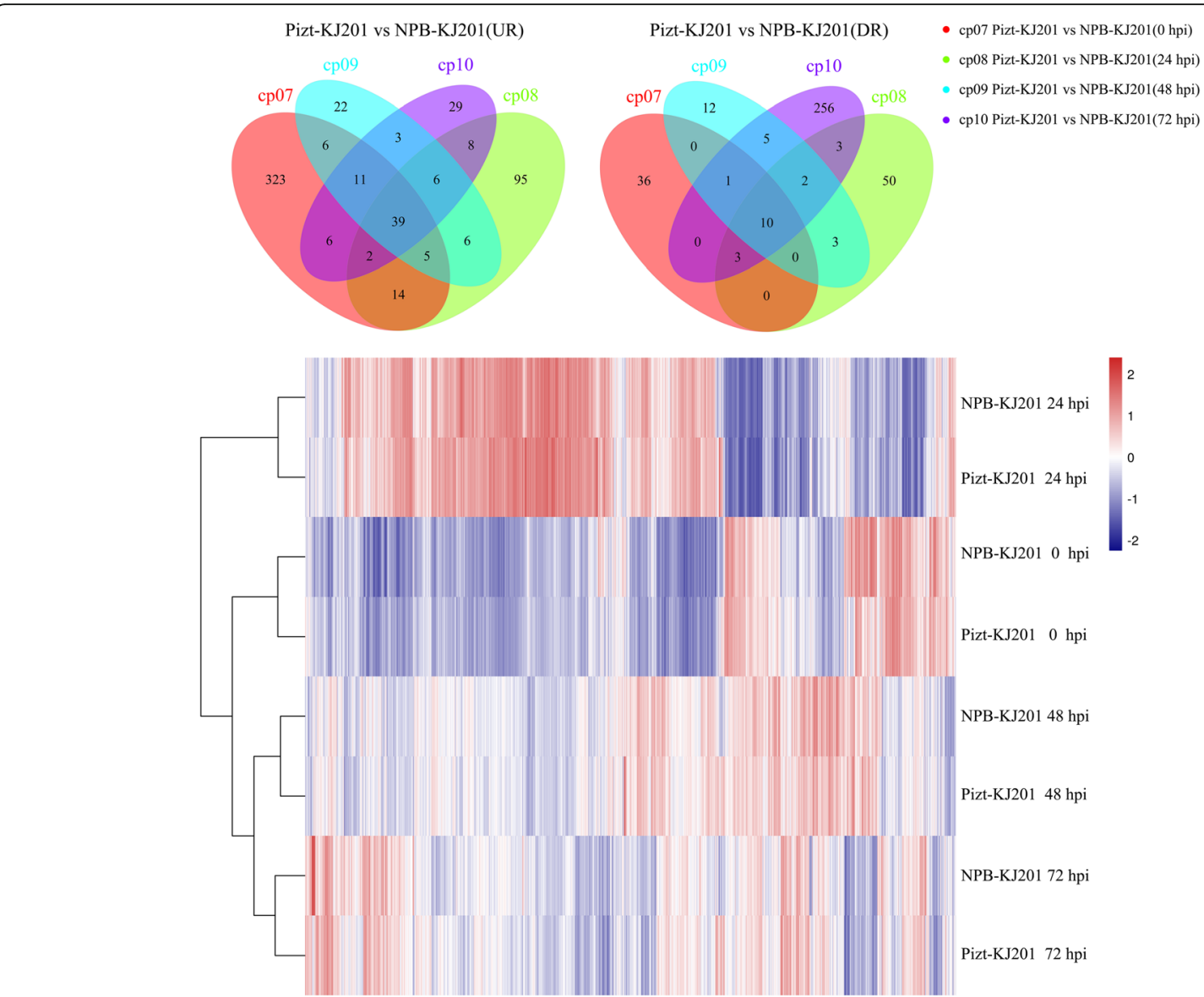

Fig. 2 Expression profile of resistant (Piz-t-KJ201) and susceptible (NPB-KJ201) lines at 0, 24, 48, and 72 hpi. a Venn diagram showing the upregulated (UR) DEGs of Piz-t-KJ201 compared to NPB-KJ201 at 0, 24, 48, and $72 \mathrm{hpi}$. b Venn diagram showing the down-regulated (DR) DEGs of Piz-t-KJ201 compared to NPB-KJ201 at 0, 24, 48, and 72 hpi. c Clustering significant (FDR adjusted $p \leq 0.05$ \& log2 fold change $\geq 2$ ) differentially expressed loci of Piz-t-KJ201 and their respective log2 fold change in NPB-KJ201. Red represents higher expression loci and blue represents lower expression loci

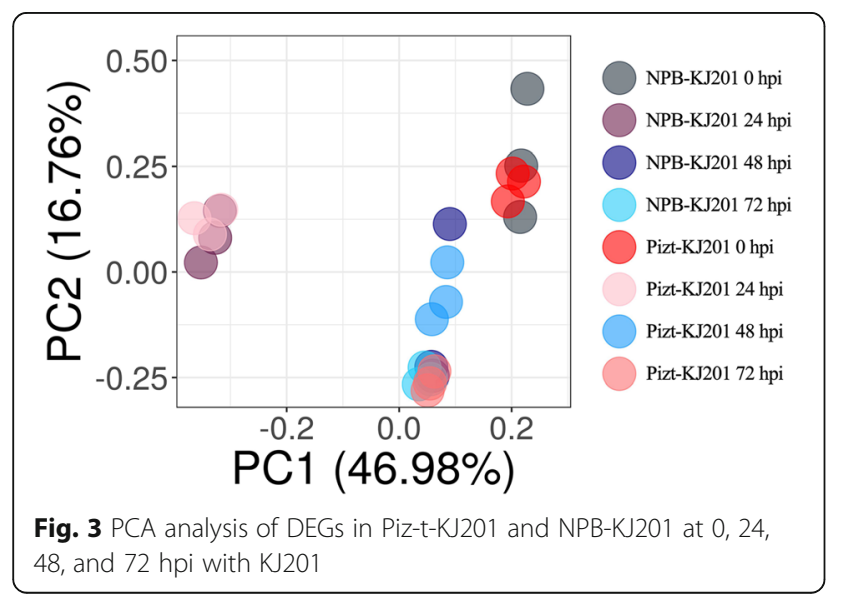

Differentially Transcriptional Profiles between Piz-t-KJ201 and NPB-KJ201 at $24 \mathrm{hpi}$

At $24 \mathrm{hpi}, 175$ and 71 genes were identified to be upregulated and down-regulated in Piz-t-KJ201 compared to NPB-Piz-t, respectively (Supplemental Table 2). To provide valuable insight into the functional associations of the 246 DEGs at the critical time-point, GO analysis of these DEGs showed that the most significant categories of biological processes were associated with auxin catabolic processes, oxazole or thiazole biosynthetic and metabolic processes. The most significant cellular component categories correlated with extracellular region, intrinsic and integral component of plasma membrane, and plasma membrane, and the most molecular function categories related to ADP binding, monooxygenase activity, oxidoreductase activity, and ion binding (Additional Fig. 2A). Kyoto Encyclopedia of Genes and Genomes (KEGG) analysis revealed that the DEGs functions were mainly involved in PPI, lysine degradation, MAPK signaling pathway, cAMP 
signaling pathway (Additional Fig. 2B). Several transcription factors (TF) such as FAR1, WRKY, NAC, and bHLH were also significantly enriched in the critical time-point (Table 1).

Next, we selected the genes of the significant PPI pathway for further analysis. Notably, four genes of MAPK signaling pathway, one WRKY-related gene, five PR1 genes, and genes of eight $\mathrm{R}$ proteins were involved in this pathway. All of these genes had significantly expressed at higher levels in Piz-t-KJ201 compared to NPB-KJ201 except LOC_Os02g41710, which had higher expression level in NPB-KJ201 (Table 1, Fig. 1c). Interestingly enough, the expression ratios of LOC_Os06g17920 and LOC_ Os06g17900 between the Piz-t-KJ201 and NPB-KJ201 were very large, and both of these two genes had small amount of expression levels in the NPB-KJ201 across the four time-points (Table 2, Fig. 1c). In a similar vein, the other four genes also had higher or specific expression in Piz-t-KJ201 (Table 1, Fig. 1c).

As the MAPKs are conserved signaling molecules that transduce pathogen stimuli into intra-cellular responses, those up-regulated MAPKs in Piz-t-KJ201 contributed to the activation of PR1s and R genes, leading to the synthesis of antimicrobial compounds such as secondary metabolites that prevent pathogen development. Additionally, several active TFs from FAR1, WRKY, NAC, and bHLH families have been demonstrated to be involved in responses to biotic and abiotic stresses (Ramamoorthy et al. 2008), which were implicated in the regulation of transcriptional reprogramming associated with early response to $M$. oryzae. Taken these genes together showed that expanded transcriptional activation may be controlled by Piz- $t$ in the PPI pathways during the early response of rice to $M$. oryzae.

\section{Gene Co-Expression Networks}

The WGCNA R package was used to construct a coexpression network consisting of the normalized read counts for the 24 samples based on 33,451 genes. The results showed 12 co-expression modules in gene membership, ranged from as low as three (grey) to as much as 5734 (turquoise) genes, as shown in Additional Tables 3, $4,5,6,7,8,9,10,11,12,13$ and 14 . These involved genes reflect that the rice- $M$. oryzae interaction is quantitative, and they represent the complexity of a cellular transcription network, from which nine SEP and three DEP modules were enriched, respectively, between NPB-KJ201 and Piz-t-KJ201 (Fig. 4). The nine SEP modules consisted of genes with similar expression profiles between NPB-KJ201 and Piz-t-KJ201 at the four time-points, suggesting the basal similarities between their transcriptional profiles; and the three DEP modules contained those genes with unique expression profiles in NPB-KJ201 or Piz-t-KJ201 at the four time-points, meaning that they may directly associate with resistance response.
The nine SEP was involved in four different types of expression pattern: (i) the turquoise and green modules: up-regulated at 0 and $24 \mathrm{hpi}$, and then down-regulated at $48 \mathrm{hpi}$, but up-regulated at $72 \mathrm{hpi}$ again (Additional Tables 3 and 4); (ii) the blue, brown, black, and magenta modules: down-regulated at 0 and $24 \mathrm{hpi}$, and then upregulated at $48 \mathrm{hpi}$, but down-regulated at $72 \mathrm{hpi}$ again (Additional Tables 5, 6, 7, 8); (iii) the red and yellow modules: up-regulated at 0,24 , and $48 \mathrm{hpi}$, but downregulated at $72 \mathrm{hpi}$ (Additional Tables 9 and 10); (iv) the green-yellow: down-regulated at 0 and $24 \mathrm{hpi}$, and upregulated at 48 and $72 \mathrm{hpi}$, with an obvious higher expression level in Piz-t-KJ201 across the four time-points compared to NPB-KJ201 (Additional Table 11). On the other hand, the DEP modules were composed of the pink, purple and grey ones. All of these three DEP modules obviously had different expression patterns between Piz-t-KJ201 and NPB-KJ201 across the four time-points (Fig. 4, Supplementary Tables 12, 13, 14). Although the purple model included some obvious DEGs between Piz-t-KJ201 and NPB-KJ201, they didn't occur at the key time-point of 24 hpi (Supplementary Tables 13). Additionally, the grey modules contained as little as 3 complete reverse regulated DEGs between Piz-t-KJ201 and NPB-KJ201, and they also had lower levels expression in Piz-t-KJ201 compared to NPB-KJ201 at $24 \mathrm{hpi}$ (Supplementary Tables 14). Intriguingly, the pink module contains a set of specific higher DEGs in Piz-t-KJ201 compared to NPB-KJ201, especially at $24 \mathrm{hpi}$, which suggests that this module involved in DEGs was unique to the resistant response (Supplementary Tables 12).

\section{Differentially Transcriptional Profiles in the Pink and the Green-Yellow Module}

We further analyzed the transcriptional profiles of the representative pink and green-yellow modules, and the results showed that 106 and 34 genes that were differentially regulated between Piz-t-KJ201 and NPB-KJ201 (Additional Tables 11 and 12). Gene ontology (GO) analysis of DEGs in the pink module showed that the most significant molecular function categories identified were ADP binding, adenyl ribonucleotide binding, adenyl nucleotide binding, ion binding, and nucleotide binding. Meanwhile, the most significant biological processes were associated with DNA integration, cell communication, and signaling transduction. In the case of DEGs in the green-yellow module, the most significant molecular function categories were chlorophyll binding, electron transporter and transfer activity, and tetrapyrrole binding. The most significant biological process categories were photosynthetic electron transport in photosystem II, protein-chromophore linkage, and photosynthesis process, while cellular component categories identified include those associated with photosystem, thylakoid, 
Table 1 The differentially expressed genes of transcription factors (TFs) and PPI pathway at $24 \mathrm{~h}$ post inoculation

\begin{tabular}{|c|c|c|c|c|}
\hline Group & $\begin{array}{l}\text { Gene } \\
\text { name }\end{array}$ & Description & $\begin{array}{l}\text { Comparison (Piz-t-KJ201 } \\
\text { vs NPB-KJ201) }\end{array}$ & Categorize by function \\
\hline \multirow[t]{14}{*}{$\mathrm{TF}$} & $\begin{array}{l}\mathrm{LOC}_{-} \\
\mathrm{Os01g06640}\end{array}$ & $\begin{array}{l}\text { Os01g0159800, basic helix-loop-helix, putative, } \\
\text { expressed }\end{array}$ & $5.01 / 2.17$ & Dof \\
\hline & $\begin{array}{l}\text { LOC_ } \\
\text { Os01g11910 }\end{array}$ & $\begin{array}{l}\text { Os01g0218100, basic helix-loop-helix, putative, } \\
\text { expressed }\end{array}$ & $14.72 / 6.42$ & WRKY \\
\hline & $\begin{array}{l}\text { LOC_ } \\
\text { Os02g14490 }\end{array}$ & $\begin{array}{l}\text { Os02g0241200, MYB family transcription factor, } \\
\text { putative, expressed }\end{array}$ & $0.27 / 1.04$ & B3 \\
\hline & $\begin{array}{l}\text { LOC_ } \\
\text { Os02g15350 }\end{array}$ & $\begin{array}{l}\text { Os02g0252400, dof zinc finger domain containing } \\
\text { protein, putative, expressed }\end{array}$ & $6.06 / 0$ & MYB \\
\hline & $\begin{array}{l}\text { LOC_ } \\
\text { Os02g36880 }\end{array}$ & $\begin{array}{l}\text { Os02g0579000, no apical meristem protein, putative, } \\
\text { expressed }\end{array}$ & $4.88 / 1.88$ & ERF \\
\hline & $\begin{array}{l}\text { LOC_- } \\
\text { Os05g03740 }\end{array}$ & $\begin{array}{l}\text { Os05g0128000, transcription factor TF2, putative, } \\
\text { expressed }\end{array}$ & $1.72 / 0.73$ & FAR1 \\
\hline & $\begin{array}{l}\text { LOC_- } \\
\text { Os05g50610 }\end{array}$ & Os05g0583000, WRKY8, expressed & $3.91 / 0.95$ & WRKY \\
\hline & $\begin{array}{l}\text { LOC_ } \\
\text { Os08g14880 }\end{array}$ & $\begin{array}{l}\text { Os08g0246800, transposon protein, putative, } \\
\text { unclassified, expressed }\end{array}$ & 21.81/9.97 & NAC \\
\hline & $\begin{array}{l}\text { LOC_ } \\
\text { Os09g28440 }\end{array}$ & $\begin{array}{l}\text { Os09g0457900, AP2 domain containing protein, } \\
\text { expressed }\end{array}$ & $0.81 / 0$ & NAC \\
\hline & $\begin{array}{l}\text { LOC_ } \\
\text { Os10g34884 }\end{array}$ & $\begin{array}{l}\text { Os10g0490300, RIPER7 - Ripening-related family pro- } \\
\text { tein precursor, expressed }\end{array}$ & 0/0.03 & $\mathrm{bHLH}$ \\
\hline & $\begin{array}{l}\text { LOC_ } \\
\text { Os10g39190 }\end{array}$ & $\begin{array}{l}\text { Os10g0537100, B3 DNA binding domain containing } \\
\text { protein, expressed }\end{array}$ & $10.11 / 0.63$ & G2-like \\
\hline & $\begin{array}{l}\text { LOC_ } \\
\text { Os11g02520 }\end{array}$ & Os11g0117400, WRKY104, expressed & $3.05 / 0.25$ & FAR1 \\
\hline & $\begin{array}{l}\text { LOC_ } \\
\text { Os11g35390 }\end{array}$ & $\begin{array}{l}\text { Os11 g0558200, MYB family transcription factor, } \\
\text { putative, expressed }\end{array}$ & $1.78 / 4.70$ & Trihelix \\
\hline & $\begin{array}{l}\text { LOC_ } \\
\text { Os12g03050 }\end{array}$ & $\begin{array}{l}\text { Os12g0123800, no apical meristem protein, putative, } \\
\text { expressed }\end{array}$ & $0.57 / 0.08$ & $\mathrm{bHLH}$ \\
\hline \multirow[t]{13}{*}{ PPI } & $\begin{array}{l}\mathrm{LOC}_{-} \\
\text {Os02g41710 }\end{array}$ & $\begin{array}{l}\text { Os02g0627700, cyclic nucleotide-gated ion channel, } \\
\text { putative, expressed }\end{array}$ & $0.09 / 0.47$ & MAPK signaling pathway \\
\hline & $\begin{array}{l}\text { LOC_ } \\
\text { Os02g47990 }\end{array}$ & $\begin{array}{l}\text { AP014958, retrotransposon protein, putative, } \\
\text { unclassified, expressed }\end{array}$ & $0.14 / 0.03$ & MAPK signaling pathway \\
\hline & $\begin{array}{l}\text { LOC_ } \\
\text { Os04g27096 }\end{array}$ & Os04g0340100, expressed protein & $3.53 / 1.00$ & MAPK signaling pathway \\
\hline & $\begin{array}{l}\text { LOC_ } \\
\text { Os06g17900 }\end{array}$ & $\begin{array}{l}\text { Os } 06 g 0286700 \text {, disease resistance protein RPM1, } \\
\text { putative, expressed }\end{array}$ & $35.65 / 0.50$ & MAPK signaling pathway \\
\hline & $\begin{array}{l}\text { LOC_ } \\
\text { Os06g17920 }\end{array}$ & $\begin{array}{l}\text { Os06g0287000, NBS-LRR disease resistance protein, } \\
\text { putative, expressed }\end{array}$ & $10.47 / 0.03$ & $\begin{array}{l}\text { WRKY DNA-binding domain containing } \\
\text { protein, expressed }\end{array}$ \\
\hline & $\begin{array}{l}\text { LOC_ } \\
\text { Os07g03279 }\end{array}$ & $\begin{array}{l}\text { Os07g0124900, SCP-like extracellular protein, } \\
\text { expressed }\end{array}$ & $51.58 / 15.30$ & OsPR1\#071 \\
\hline & $\begin{array}{l}\text { LOC_ } \\
\text { Os07g03319 }\end{array}$ & $\begin{array}{l}\text { Os07g0125201, SCP-like extracellular protein, } \\
\text { expressed }\end{array}$ & $2.49 / 0.56$ & OsPR1\#072 \\
\hline & $\begin{array}{l}\text { LOC_ } \\
\text { Os07g03368 }\end{array}$ & $\begin{array}{l}\text { Os07g0124900, SCP-like extracellular protein, } \\
\text { expressed }\end{array}$ & $113.56 / 34.77$ & OsPR1\#072 \\
\hline & $\begin{array}{l}\text { LOC_ } \\
\text { Os07g03499 }\end{array}$ & $\begin{array}{l}\text { Os07g0125201, SCP-like extracellular protein, } \\
\text { expressed }\end{array}$ & $3.47 / 0.74$ & OsPR1\#072 \\
\hline & $\begin{array}{l}\text { LOC_ } \\
\text { Os07g03600 }\end{array}$ & $\begin{array}{l}\text { Os07g0127700, SCP-like extracellular protein, } \\
\text { expressed }\end{array}$ & $1.39 / 0.28$ & OsPR1\#074; PR-1a \\
\hline & $\begin{array}{l}\text { LOC_ } \\
\text { Os07g12240 }\end{array}$ & AP014963, EF hand family protein, putative, expressed & $0.13 / 0$ & $\mathrm{R}$ protein, expressed \\
\hline & $\begin{array}{l}\text { LOC_ } \\
\text { Os11g02520 }\end{array}$ & Os11g0117400, WRKY104, expressed & $3.05 / 0.25$ & $\mathrm{R}$ protein, expressed \\
\hline & LOC_ & Os11g0224900, disease resistance protein RPM1, & $8.44 / 0.25$ & $\mathrm{R}$ protein, expressed \\
\hline
\end{tabular}


Table 1 The differentially expressed genes of transcription factors (TFs) and PPI pathway at $24 \mathrm{~h}$ post inoculation (Continued)

\begin{tabular}{|c|c|c|c|c|}
\hline Group & $\begin{array}{l}\text { Gene } \\
\text { name }\end{array}$ & Description & $\begin{array}{l}\text { Comparison (Piz-t-KJ201 } \\
\text { vs NPB-KJ201) }\end{array}$ & Categorize by function \\
\hline & Os11g11770 & putative, expressed & & \\
\hline & $\begin{array}{l}\text { LOC_ }_{-} \\
\text {Os11g11810 }\end{array}$ & $\begin{array}{l}\text { Os } 11 \text { g0225300, NBS-LRR disease resistance protein, } \\
\text { putative, expressed }\end{array}$ & $5.60 / 0$ & R protein, expressed \\
\hline & $\begin{array}{l}\text { LOC_ } \\
\text { Os11911920 }\end{array}$ & Os11g0226400, resistance protein, putative, expressed & $7.17 / 0$ & $R$ protein, expressed \\
\hline & $\begin{array}{l}\text { LOC } \\
\text { Os11911990 }\end{array}$ & $\begin{array}{l}\text { Os11g0227100, NB-ARC domain containing protein, } \\
\text { expressed }\end{array}$ & $5.78 / 2.51$ & R protein, expressed \\
\hline & $\begin{array}{l}\text { LOC }_{-} \\
\text {Os11g43700 }\end{array}$ & Os11g0657900, RGH1A, putative, expressed & $1.23 / 0.54$ & R protein, expressed \\
\hline & $\begin{array}{l}\mathrm{LOC}_{-} \\
\text {Os12g17430 }\end{array}$ & $\begin{array}{l}\text { AP014968, NBS-LRR disease resistance protein, puta- } \\
\text { tive, expressed }\end{array}$ & $4.01 / 0.54$ & R protein, expressed \\
\hline
\end{tabular}

and membrane protein complex. KEGG analysis also revealed that DEGs specific to the pink module were mainly involved in pathways related to PPI, while DEGs specific to the green-yellow module were mainly associated with the photosynthesis (Table 3 ).

Five resistance genes of LOC_Os11g11810, LOC Os06g17920, LOC_Os11g11770, LOC_Os06g17900, and LOC_Os11g11920 involved in PPI pathway and one TF of LOC_Os10g39190 are the most significant element in the pink module (Table 2, Fig. 1c, Additional Fig. 3). Interestingly, LOC_Os06g17900 and LOC_Os06g17920, two putative pseudogenes of the Pi2/9 homologous showed the first and second highest values, respectively, and three activated NLR genes of LOC_Os11g11810, LOC_Os11g11770, and LOC_Os11g11920 in Piz-tKJ201 have been reported to associate with important agronomic traits. Another TF of LOC_Os10g39190 perhaps involved in ABA signaling regulation was significantly up-regulated in Piz-t-KJ201 plants across four time-points, especially at 24 hpi (Table 2, Fig. 1c, Additional Fig. 3).

Next, we focused on the functional analysis of LOC Os10g39190. One gRNA locating in the $345 \mathrm{bp}$ of Os10g053710 was designed to silence this gene (Additional Fig. 4). Although we obtained six CRISPR mutants, but all of these transgenic plants didn't survive at the seedling stage.

\section{Discussion}

In this study, we showed an approach in evaluating large transcription data using co-expression networks in combination with the critical time-point at $24 \mathrm{hpi}$ analysis. Specifically, we applied this strategy in analyzing gene expression dataset from rice in response to $M$. oryzae infection and identifying genes possibly involved in rice against $M$. oryzae, In this study, we identified several significant DEGs related with TF, MAPK signaling pathway, OsPR1, and $\mathrm{R}$ proteins of genes to be possibly involved in the resistance response in the Piz-t-KJ201 interaction, facilitating understanding the interaction of rice- $M$. oryzae and breeding for new resistant cultivars.

\section{Resistance Response Involved in the Regulation of Photosynthesis}

Previously, it has been reported that both pathogenassociated molecular pattern (PAMP) -triggered immunity (PTI) and effector-triggered immunity (ETI) contribute to the resistance response to rice blast (Boller and Felix 2009), and NLR-mediated immunity is known to be modulated by many environmental factors such as light (Gao et al. 2020). In the present study, nine SEP between Piz-t-KJ201 and NPB-KJ201 were found, especially green-yellow module, in which the photosystem plays a vital role. Previous studies

Table 2 The specific differentially expressed genes in the pink module

\begin{tabular}{|c|c|c|c|c|c|}
\hline \multirow[t]{2}{*}{ Gene_name } & \multirow[t]{2}{*}{ Description } & \multicolumn{4}{|c|}{ Comparison (Piz-t-KJ201/NPB-KJ201) } \\
\hline & & 0 hpi & 24 hpi & 48hpi & 72 hpi \\
\hline LOC_Os06g17900 & Os06g0286700, disease resistance protein, putative, expressed & $38.87 / 0.78$ & $35.65 / 0.50$ & $35.94 / 0.55$ & $28.08 / 0.57$ \\
\hline LOC_Os06g17920 & Os06g0287000, NBS-LRR disease resistance protein, putative, expressed & $11.66 / 0.16$ & $10.47 / 0.03$ & $11.19 / 0$ & $7.93 / 0.07$ \\
\hline LOC_Os10g39190 & Os10g0537100, B3 DNA binding domain containing protein, expressed & $3.76 / 0.11$ & $10.11 / 0.63$ & $5.08 / 0.53$ & $7.19 / 1.15$ \\
\hline LOC_Os11g11770 & Os11g0224900, disease resistance protein RPM1, putative, expressed & $1.44 / 0.19$ & $8.44 / 0.25$ & $2.95 / 0.16$ & $1.85 / 0.34$ \\
\hline LOC_Os11g11810 & Os11g0225300, NBS-LRR disease resistance protein, putative, expressed & $2.61 / 0.14$ & $5.60 / 0$ & $3.10 / 0.008$ & $3.77 / 0.08$ \\
\hline LOC_Os11g11920 & Os11g0226400, resistance protein, putative, expressed & $3.66 / 0.25$ & $7.17 / 0$ & $4.66 / 0.02$ & $6.30 / 0.22$ \\
\hline
\end{tabular}




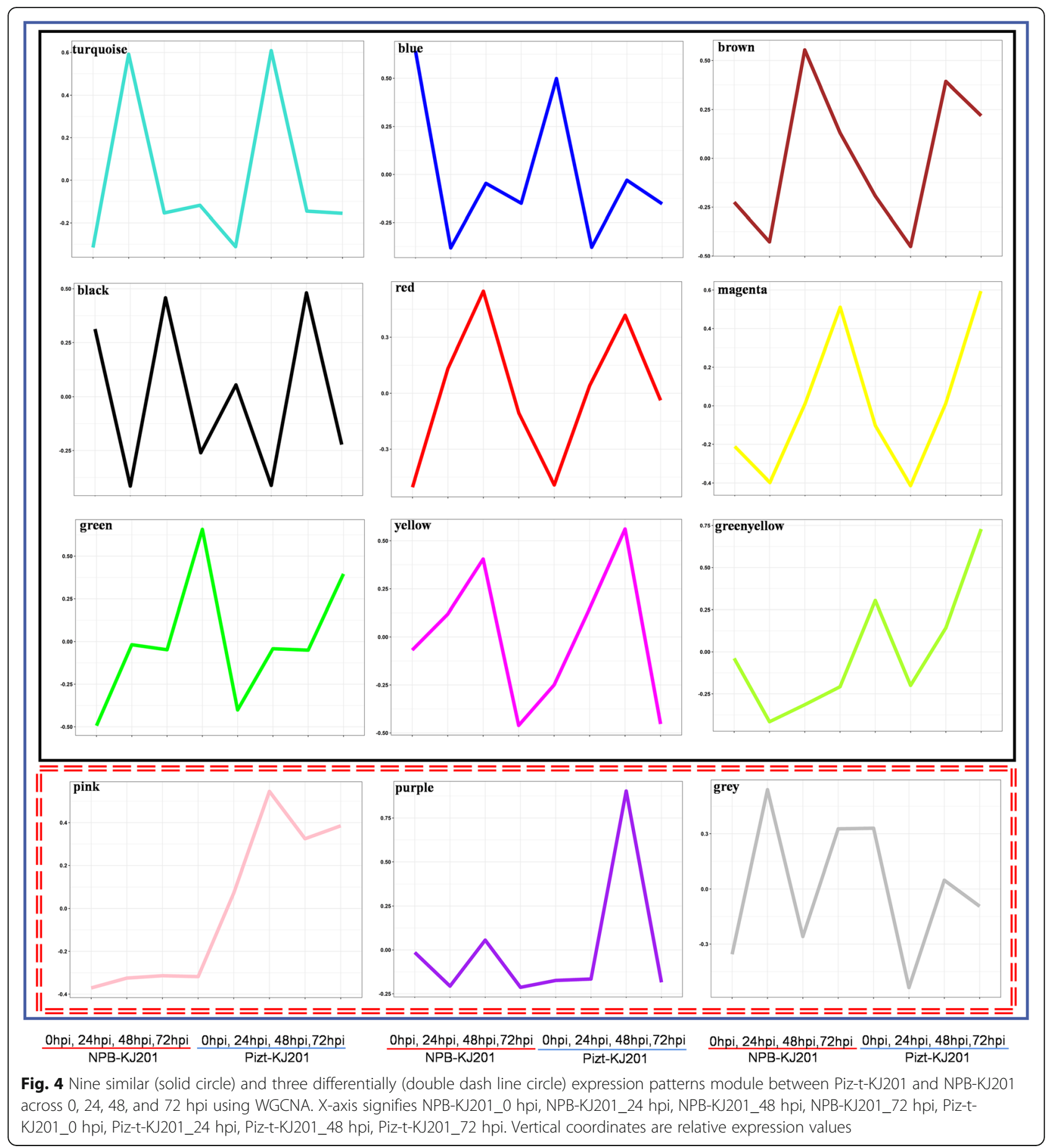

confirmed that photosystem was easily targeted by different pathogenic species such as bacteria, viruses, fungi and oomycetes to produce cytoplasmic calcium bursts, jasmonic acid, salicylic acid, and reactive oxygen species, resulting in transcriptional reprogramming to mount a full defense response (Fondong et al. 2007; Jelenska et al. 2007; Rodriguez-Herva et al. 2012; Nomura et al. 2012; Li et al. 2014a, b; Petre et al. 2016; Sowden et al. 2018; Liu et al. 2018; Rosas-Diaz et al. 2018). Subsequently, the photosystem needs to be restored in time to prevent or reduce the damage and energy costs, which can be obviously shown in the green-yellow module with higher expression in Piz-t-KJ201. 
Table 3 The number of significant differentially expressed genes in pink and yellow-green present in different GO and KEGG terms

\begin{tabular}{|c|c|c|c|c|c|}
\hline Module & GO Accessions & Term types & Go Terms & Number of DEGs & $P$-value \\
\hline \multirow[t]{10}{*}{ Pink } & GO:0015074 & Biological process (BP) & DNA integration & 6 & $8.70 \mathrm{E}-06$ \\
\hline & GO:0007154 & Biological process (BP) & cell communication & 10 & 0.00062 \\
\hline & GO:0007165 & Biological process (BP) & signal transduction & 9 & 0.00095 \\
\hline & GO:0023052 & Biological process (BP) & signaling & 9 & 0.00095 \\
\hline & GO:0043531 & Molecular function (MF) & ADP binding & 15 & $2.2 \mathrm{E}-12$ \\
\hline & GO:0032559 & Molecular function (MF) & adenyl ribonucleotide binding & 23 & 0.000034 \\
\hline & GO:0030554 & Molecular function (MF) & adenyl nucleotide binding & 23 & 0.000035 \\
\hline & GO:0043167 & Molecular function (MF) & ion binding & 35 & 0.000056 \\
\hline & GO:0000166 & Molecular function (MF) & nucleotide binding & 25 & 0.000057 \\
\hline & ko04626 & Pathway & Plant-pathogen interaction & 8 & 0.000883 \\
\hline \multirow[t]{14}{*}{ green-yellow } & GO:0009772 & Biological process (BP) & photosynthetic electron transport in photosystem II & 7 & $2.70 \mathrm{E}-17$ \\
\hline & GO:0018298 & Biological process (BP) & protein-chromophore linkage & 8 & 7.70E-17 \\
\hline & GO:0009767 & Biological process (BP) & photosynthetic electron transport chain & 8 & $6.9 \mathrm{E}-16$ \\
\hline & GO:0019684 & Biological process (BP) & photosynthesis, light reaction & 9 & $9.20 \mathrm{E}-15$ \\
\hline & GO:0015979 & Biological process (BP) & photosynthesis & 10 & $1.00 \mathrm{E}-13$ \\
\hline & GO:0016168 & Molecular function (MF) & chlorophyll binding & 8 & $1.6 \mathrm{E}-16$ \\
\hline & GO:0045156 & Molecular function (MF) & electron transporter & 7 & $1.30 \mathrm{E}-15$ \\
\hline & GO:0009055 & Molecular function (MF) & electron transfer activity & 7 & 9.40E-09 \\
\hline & GO:0046906 & Molecular function (MF) & tetrapyrrole binding & 8 & 3.50E-07 \\
\hline & GO:0009521 & Cellular component (CC) & photosystem & 10 & $2.00 \mathrm{E}-16$ \\
\hline & GO:0009523 & Cellular component (CC) & photosystem II & 8 & 1.40E-13 \\
\hline & GO:0034357 & Cellular component (CC) & photosynthetic membrane & 10 & 4.70E-12 \\
\hline & GO:0044436 & Cellular component (CC) & thylakoid part & 10 & $7.80 \mathrm{E}-12$ \\
\hline & ko00195 & Pathway & Photosynthesis & 9 & $6.53 \mathrm{E}-11$ \\
\hline
\end{tabular}

PPI Pathway-Related Differentially Expressed Genes at 24 hpi

PPI was the significant affected pathway in both the pink module and the time-point of $24 \mathrm{hpi}$. Specially for the 24 hpi, LOC_Os02g41710 (CNGC) was the only MAPK signaling pathway gene that had lower expression in Pizt-KJ201 as compared with NPB-KJ201. This gene negatively regulates flow of extracellular $\mathrm{Ca}^{2}+$ (Monné et al. 2015). Although the other three MAPK signaling pathway genes were up-regulated in Piz-t-KJ201, complete understanding of their roles in rice disease resistance still remains unclear. Interestingly, five OsPR1 encoding SCPlike extracellular protein were identified to be upregulated in Piz-t-KJ201, suggesting that they may play particular roles in resistance response. Similarly, there were also evidences that the expression of PR1a and PR1b were related to disease resistance (Ponciano et al. 2006).

Several TFs of WRKY, bHLH, AP2/ERF, Dof, MYB, and NAC etc. were significantly differentially expressed between Piz-t-KJ201 and NPB-KJ201. These members of the TF families have been confirmed to be involved in regulating rice defense responses to $M$. oryzae (Licausi et al. 2013; Yokotani et al. 2014; Cheng et al. 2015). Thus, they may play important roles in the regulation of defenseresponsive genes. The WRKY104 was a positive regulator enhancing the resistance to $M$. oryzae by up-regulating pathogenesis- related (PR) genes as also shown in recent reports (Hou et al. 2019). Additionally, the higher expression of $R$ genes LOC_Os11g11990, LOC_Os11g43700, and LOC_Os12g17430 in the Piz-t-KJ201 interaction system were also observed, which have also been implicated in stress responses (Zheng et al. 2014).

\section{Several Putative NLR Pairs with Piz-t Helper to Mediate Immune Signaling}

Plant $R$ genes detect effector proteins secreted by pathogens by indirectly or directly binding them via effector-targeted host proteins, with a complex scenario of sequential action of "sensor" NLRs to detect pathogen effectors and "helper" NLRs to initiate immune signaling (Wu et al. 2017). The pink module is the most representative DEP, which includes 6 significant DEGs between Piz-t-KJ201 and NPBKJ201 across the four time-points. The alleles of LOC_ Os06g17920 and LOC_Os06g17900 of Piz-t locus were regarded as $R$ pseudogenes in the rice Nipponbare genome (Wu et al. 2012). However, when the prediction was based 
on our present study, these two pseudogenes were actually not pseudogenes but always highly expressed in Piz-tKJ201 compared to NPB-KJ201 (Table 2). Thus, they are maybe functionally redundant with Piz-t as helper NLR activated by sensors NLR. The specific expressions and characteristics of the alleles of LOC_Os06g17920 and LOC_ Os06g17900 in Piz-t-KJ201 deserve further explorations.

In addition, LOC_Os11g11810 and LOC_Os11g11770 were identified to be known Pia and RPM1, respectively (Okuyama et al. 2011; Yoo et al. 2017; Onaga et al. 2017). Previous studies identified that Pia encodes a NBS-LRR disease resistance protein that are known to contribute to weak resistance to rice blast (Okuyama et al. 2011; Césari et al. 2013; Jung et al. 2013); while RPM1 encodes NB-ARC domain containing protein and can be activated by the defense protein RIN4 to sense effector, and then transmit signals downstream (Li et al. 2014a, b), suggesting that the two genes confer to resistance as the sensor NLRs. Moreover, both of LOC_ Os11g11810 and LOC_Os11g11770 were identified to be nonsynonymous single nucleotide polymorphism NLR genes, and another NLR gene of LOC_Os11g11920 was also down-regulated at developmental period in black rice (functional cultivar) (Seol et al. 2016), implying that they likely play an important role in determining agronomic traits differences. This is consistent with the previous report that a complex relationship exist between disease resistance and yield-related components (Wang et al. 2015).

The B3-domain transcription factor abscisic acidinsensitive 3 (ABI3) was a central regulator in ABA signaling (Zhang et al. 2005). However, to date, there are still a few examples of functional validation of the roles being played by B3 in plant defense. Unfortunately, in the functional identification of LOC_Os10g39190 via CRISPR-Cas9, we can't get the transgenic seed as all of the $\mathrm{T}_{0}$ generation of transgenic plants died at the seedling stage. In general, the effect of knocking out 1 member of the paired NLRs was more severe in some sensor mutants compared to some helper mutants, which usually led to the death of the mutants (Wang et al. 2019), from which we can infer that LOC_Os10g39190 maybe as a potential important sensor member.

\section{Validation of the Present Study by Comparing Previous Reports}

In our earlier studies, four proteins of a receptor-like protein kinase (gi|59,800,021), a NADP dependent malic enzyme (gi|54,606,800), a putative transaldolase (gi|57, $900,129)$, and a putative bowman birk trypsin inhibitor (gi|53,792,234), three C3HC4-type Ring finger E3 ubiquitin ligase (APIP2, 6, 10), and a bowman-Birk type bran trypsin inhibitor (APIP4) were confirmed to be involved in Piz-t-KJ201 interaction (Park et al. 2012, 2016;
Tian et al. 2018; Zhang et al. 2020). In the present study, we observed that a receptor-like protein kinase precursor (LOC_Os10g33040), a NADP-dependent malic enzyme (LOC_Os05g09440), a transaldolase (LOC_ Os08g05830), a bowman-Birk type bran trypsin inhibitor precursor (LOC_Os01g03360), and two zinc finger C3HC4 type domain containing protein (LOC_ Os01g20910 and LOC_Os12g04590) were also differentially regulated in Piz-t-KJ201 (Additional Table 2). Therefore, parts of the present results were validated by the previous studies. Though we tried to identify the function of LOC_Os10g39190, it's regretful that the mutant can't survive at the seedling stage.

This research reveals that many genes are involved in the defense network of Piz-t-KJ201, consistent with previous observations (Park et al. 2012, 2016; Wang et al. 2019; Bai et al. 2019; Zhang et al. 2020). These genes and TFs identified in the present study were of high biological relevance. It was their pairs and interactive $N L R$ network that confer blast resistance in the Piz-t-KJ201 interaction as described in the former researches (Wu et al. 2017; Baggs et al. 2017; Wang et al. 2019).

\section{Conclusion}

In this study, we identified that the 24 hpi is the critical time-point during early stage pathogenesis, from which four genes of MAPKs signaling pathway, one gene related to WRKY DNA-binding domain containing protein, five OsPR1s genes, and three genes of $\mathrm{R}$ proteins were confirmed involved in the significant PPI pathway. In addition, nine SEP modules and three DEP modules between NPBPiz-t and NPB were also identified, among which the most representative SEP green-yellow module is associated with photosynthesis, and DEP pink module comprised of two specific expressed NLR genes of LOC_Os06g17900 and LOC_Os06g17920 of the Pi2/9 homologs, three NLR genes of LOC_Os11g11810, LOC_Os11g11770, and LOC_ Os11g11920 which are putatively associated with important agronomic traits, and a B3 DNA binding domain containing protein related genes (LOC_Os10g39190). Knockout of LOC_Os10g39190 via CRISPR-Cas9 was done, however, transgenic plants failed to survive at the seedling stage. It suggested that Piz- $t$ with these NLRs and regulators network might play important roles in the regulation of the resistance response in the Piz-t-KJ201 interaction system. The identified genes provide a valuable resource to study the rice- $M$. oryzae interaction system and facilitate breeding of new blast-resistant cultivars in the future.

\section{Methods}

Materials and Methods

Plant Materials and Blast Isolates

Rice (Oryza sativa L.) lines, including NPB and its transgenic line with Piz-t (NPB-Piz-t), and the M. oryzae 
isolates KJ201 was used in this study (Tian et al. 2018). Rice plants were grown in the greenhouse and kept under natural conditions about $2 \sim 3$ weeks (3-4 leaves). Spores concentration in the suspension was adjusted to $5 \times 10^{5}$ conidia $/ \mathrm{mL}$. After spray-inoculated, the seedlings were maintained in the dark for $24 \mathrm{~h}$ at $28^{\circ} \mathrm{C}$ and then kept under high humidity over $95 \%$ for about a week for symptom evaluation.

Leaf tissues were collected from each rice line at 0,24 , 48 , and $72 \mathrm{hpi}$ and frozen in liquid nitrogen. Some leaves of NPB-KJ201 showed obvious disease lesion, while Piz-t-KJ201 had no disease symptoms at 7 days post inoculation (Fig. 1a).

\section{Sample Preparation}

The total RNA from the infected leaves was extracted using the RNAeasy kit (Qiagen, Germany) and treated with an RNase-Free DNase Set (Qiagen, Germany), according to the manufacturer's instructions. The RNA quality, library construction and size were assayed using a 2100 Bioanalyzer system (Agilent, USA). The libraries were synthesized using the TruSeq RNA Sample Preparation v2 kit (Illumina, USA). Total RNA from each treatment was pooled and then libraries were constructed as showed in Fig. 1b and used for sequencing. The samples were run in the NovaSeq system and raw sequences of paired 150-bp were obtained.

\section{Sequences Processing and Analysis}

FastQC was used to estimate the raw reads and assess their quality. Trimming of reads was carried in Trimmomatic and reads containing contaminant primer/adapters and long stretches of poor-quality bases were removed. Each sample was mapped back onto $O$. sativa reference genome from the MSU Rice Genome Annotation Project (MSU Rice Genome Annotation Project Release 7, RGAP7) (Kawahara et al. 2013). Redundancies were removed using Picard suite of tools (http://broadinstitute. github.io/picard/). Alignment was performed using the metrics module of SAMtools (Li et al. 2009a, b). And read counts were estimated using featuresCounts (Anders et al. 2015). Normalization and differential expression analysis was performed using EdgeR (Anders and Huber 2010).

For a given genotype, significant DEGs at each timepoint were identified based on fold change (FC) (ratio of number of transcripts in inoculated sample to the number of transcripts in the mock control $\geq 2$ or $\leq 0.5$ and a $p$-value $<0.05)$.

\section{Bioinformatics Analysis}

Clustering and PCA were done using the R package. Biological processes, cellular components, and molecular functions of DEGs were determined by GO database annotation (http://www.geneontology.org/). Protein signaling pathways were elucidated using the KEGG database (http://www.genome.jp/kegg/ pathway. html). Pathways enriched at $P$-value $<0.05$ were considered significant.

\section{Co-Expression Network Analysis}

Using RSEP version 1.1.1 to quantify expression levels of genes in terms of FPKM (fragments per kilo base of exon per million)1 (Li and Dewey 2011), a common expression matrix for Piz-t-KJ201 and NPB-KJ201 at 0, 24, 48, and 72 hpi was constructed, with three replicates from each condition resulting in a total of 24 samples. Co-expression analysis was performed using $\mathrm{R}$ package. The similarity between gene-pairs was computed using a signed Pearson's correlation matrix, scaled to power $\beta=11$, based on the approximate scale free-topology criterion.

\section{Real-Time PCR Validation}

Real-time PCR (qRT-PCR) was used to validate DEGs obtained from RNA-Seq. Primers were designed using Primer 5 and summarized in Supplementary File 2. The ProtoScript M-MuLV First Strand cDNA Synthesis Kit (NEB) was used to synthesize cDNA. The reaction was performed in the LightCyclerR 480 II PCR system (Roche) with a volume of $10 \mu \mathrm{l}$, containing $5 \mu \mathrm{l}$ of SYBR Green I Master mix, $0.8 \mu \mathrm{M}$ of forward primer, $0.8 \mu \mathrm{M}$ reverse primer, $2 \mu \mathrm{l}$ of $1: 5$ diluted cDNA template (1$2 \mu \mathrm{g})$ and RNAse free water. Actin was used as the internal control. The efficiency of qRT-PCR was calculated in both control and target samples, and FC was calculated using CT method.

\section{Additional Files}

Additional file 1 : Figure S1. Expression profile of resistant (Piz-t-KJ201) and susceptible (NPB-KJ201) lines with three repeats at 0 hpi (A), 24hpi (B), 48 hpi (C), and 72 hpi (D), respectively.

Additional file $\mathbf{2}$ : Figure S2. Bioinformatic analysis of differentially expressed genes in NPB-Piz-t compared to NPB in response to M. oryzae KJ201. A, GO analysis of differentially expressed genes of NPB-Piz-t compared to NPB. B, KEGG analysis of differentially expressed genes of NPBPiz-t compared to NPB. C, Transcript factor of differentially expressed genes. The results are summarized in three main categories: biological process, cellular component, and molecular function.

Additional file $\mathbf{3}$ : Figure S3. The qRT-PCR validation of the differentially expressed gene of between NPB-Piz-t and NPB inoculated with KJ201 at 0,48 and $72 \mathrm{hpi}$ in the pink module. The data were log2 transformed for FC.

Additional file 4 : Figure S4. Functional analysis of Os10g0537100 using the CRISPR-Cas9 gene editing strategy.

Additional file $\mathbf{5}$ : Table S1. Primers used for real-time quantitative PCR used in the study.

Additional file $\mathbf{6}$ : Table S2. The information of differentially expressed genes between Piz-t-KJ201 and NPB-KJ201 at $24 \mathrm{hpi}$.

Additional file 7 : Table S3. The genes information in turquoise module. 


\begin{abstract}
Additional file 8 : Table S4. The genes information in green module.
Additional file 9 : Table S5. The genes information in blue module.

Additional file 10 : Table $\mathbf{5 6}$. The genes information in brown module.

Additional file 11 : Table S7. The genes information in black module.

Additional file 12 : Table S8. The genes information in magenta

module.

Additional file 13 : Table S9. The genes information in red module.

Additional file 14 : Table S10. The genes information in yellow module.
\end{abstract}

Additional file 15 : Table S11. The genes information in green-yellow module.

Additional file 16 : Table S12. The genes information in pink module. Additional file 17 : Table S13. The genes information in purple module.

Additional file 18 : Table S14. The genes information in grey module.

\section{Abbreviations}

DEP: Differential patterns of expression; SEP: Similar patterns of expression; WGCNA: Weighted gene co-expression network analysis; PCA: Principal component analysis; NPB: Nipponbare; NPB-Piz-t: Nipponbare transgenic line containing Piz-t; NPB-KJ201: Nipponbare inoculated with blast fungus Magnaporthe oryzae; Piz-t-KJ201: NPB-Piz-t inoculated with blast fungus Magnaporthe oryzae; PPI: Protein-protein interaction; MAPK: Mitogenactivated protein kinase; NLR: Nucleotide-binding domain and leucine-rich repeat-containing; R: Resistance; OsPR: Pathogenesis-related protein; DEG: Differentially expression gene; PRR: Pattern-recognition receptor; PAMP: Pathogen-associated molecular pattern; PTI: PAMP-triggered immunity; ETI: Effector-triggered immunity; Avr: Avirulence; TF: Transcription factor; GO: Gene ontology; KEGG: Kyoto Encyclopedia of Genes and Genomes

\section{Acknowledgements}

We are grateful to Dr. YL Jia for editing the manuscript. This work was supported by the Youth Program of Fujian Academy of Agricultural Sciences (FAAS) grant (YC2019004), Nurturing National Nature Science Foundation of China (NSFC) Research Project (GJPY2019002), and the Natural Science Foundation of Fujian Province (2014 J01 102) to DT, and the National Key R\&D Program of China (2016YFD0300700) to ZW.

\section{Authors' Contributions}

DT conceived and designed the experiments. DT, ZQC, ZJC and YL conducted experiment and analyzed the data. DT wrote and KTB, ZW and FW revised the manuscript. All authors read and approved the final manuscript.

\section{Funding}

This work was supported by the Youth Program of Fujian Academy of Agricultural Sciences (FAAS) grant (YC2019004), Nurturing National Nature Science Foundation of China (NSFC) Research Project (GJPY2019002), and the Natural Science Foundation of Fujian Province (2014 J01102) to DT, and the National Key R\&D Program of China (2016YFD0300700) to ZW.

\section{Availability of Data and Materials}

The RNA sequencing data have been submitted to the Sequence Read Archive (SRA) database (https://www.ncbi.nlm.nih.gov/sra) under the accession number PRJNA637691.

All data generated or analysed during this study are included in this published article [and its supplementary information files].

\section{Ethics Approval and Consent to Participate}

Not applicable.

\section{Consent for Publication}

Not applicable.

\section{Competing Interests}

The authors declare no conflicts of interest.

\section{Author details}

'Biotechnology Research Institute, Fujian Provincial Key Laboratory of Genetic Engineering for Agriculture, Fujian Academy of Agricultural Sciences, Fuzhou 350003, China. ${ }^{2}$ State Key Laboratory of Ecological Pest Control for Fujian and Taiwan Crops, College of Life Science, Fujian Agriculture and Forestry University, Fuzhou, China. ${ }^{3}$ Graduate School of Bioagricultural Sciences, Nagoya University, Nagoya, Japan.

Received: 15 June 2020 Accepted: 13 November 2020

Published online: 11 December 2020

\section{References}

Anders S, Huber W (2010) Differential expression analysis for sequence count data. Genome Biol 11:R106. https://doi.org/10.1038/npre.2010.4282.2

Anders S, Pyl PT, Huber W (2015) HTSeq-A Python framework to work with highthroughput sequencing data. Bioinformatics 31:166-169. https://doi.org/10. 1093/bioinformatics/btu638

Ashkani S, Rafii M, Shabanimofrad M, GhaSEPzadeh A, Ravanfar SA, Latif MA (2016) Molecular progress on the mapping and cloning of functional genes for blast disease in rice (Oryza sativa L.): current status and future considerations. Crit Rev Biotechnol 36:353-367. https://doi.org/10.3109/ 07388551.2014 .961403

Baggs E, Dagdas G, Krasileva KV (2017) NLR diversity, helpers and integrated domains: making sense of the NLR IDentity. Curr Opin Plant Biol 38:59-67. https://doi.org/10.1016/j.pbi.2017.04.012

Bagnaresi P, Biselli C, Orrù L, Urso S, Crispino L, Abbruscato P, Piffanelli P, Lupotto E, Cattivelli L, Vale G (2012) Comparative transcriptome profiling of the early response to Magnaporthe oryzae in durable resistant vs susceptible rice (Oryza sativa L.) genotypes. PLoS One 7:e51609. https://doi.org/10.1371/ journal.pone.0051609

Bai P, Park CH, Shirsekar G, Songkumarn P, Bellizzi M, Wang GL (2019) Role of lysine residues of the Magnaporthe oryzae effector AvrPiz-t in effector- and PAMP- triggered immunity. Mol Plant Pathol 20:599-608. https://doi.org/10 1111/mpp.12779

Boller T, Felix G (2009) A renaissance of elicitors: perception of microbe associated molecular patterns and danger signals by pattern-recognition receptors. Annu Rev Plant Biol 60:379-406. https://doi.org/10.1146/annurev. arplant.57.032905.105346

Cao JD, Yang C, Li L, Jiang L, Wu Y, Wu CW, Bu QY, Xia GX, Liu XY, Luo YM, Liu J (2016) Rice plasma membrane proteomics reveals Magnaporthe oryzae promotes susceptibility by sequential activation of host hormone signaling pathways. Mol Plant Microbe Interact 29:902-913. https://doi.org/10.1094/ MPMI-08-16-0165-R

Césari S, Guillen KD, Cesari S, Chalvon V, Michel C, Jauneau A, Rivas S, Alaux L, Kanzaki H, Okuyama Y, Morel JB, Fournier E, Tharreau D, Terauchi R, Kroj T (2013) The rice resistance protein pair RGA4/RGA5 recognizes the M. oryzae effectors AVR-Pia and AVR1- CO39 by direct binding. Plant Cell 25:1463-1481. https://doi.org/10.1105/tpc.112.107201

Cheng H, Liu H, Deng Y, Xiao J, Li X, Wang S (2015) The WRKY45-2 WRKY13 WRKY42 transcriptional regulatory cascade is required for rice resistance to fungal pathogen. Plant Physiol 167:1087-1099. https://doi.org/10.1104/pp. 114.256016

Fondong VN, Reddy RC, Lu C, Hankoua B, Felton C, Czymmek K, Achenjang F (2007) The consensus N-myristoylation motif of a geminivirus AC4 protein is required for membrane binding and pathogenicity. Mol Plant-Microbe Interact 20:380-391. https://doi.org/10.1094/MPMI-20-4-0380

Gao CY, Xu HW, Huang J, Sun BY, Zhang F, Savage Z, Duggan C, Yan TX, Wu CH, Wang YC, Vleeshouwers V, Kamoun S, Bozkurt TO, Dong SM (2020) Pathogen manipulation of chloroplast function triggers a light-dependent immune recognition. Proc Natl Acad Sci USA 117:9613-9620. https://doi.org/10.1073/ pnas.2002759117

Hou YX, Wang YF, Tang LQ, Tong XH, Wang L, Liu LM, Huang SW, Zhang J (2019) SAPK10-mediated phosphorylation on WRKY72 releases its suppression on jasmonic acid biosynthesis and bacterial blight resistance. IScience 28:499510. https://doi.org/10.1016/j.isci.2019.06.009

Jain P, Singh PK, Kapoor R, Khanna A, Solanke AU, Krishnan SG, Singh AK, Sharma $V$, Sharma TR (2017) Understanding host-pathogen interactions with expression profiling of NILs carrying rice-blast resistance Pi9 gene. Front Plant Sci 8:93. https://doi.org/10.3389/fpls.2017.00093

Jelenska J, Yao N, Vinatzer BA, Wright CM, Brodsky JL, Greenberg JT (2007) AJ domain virulence effector of Pseudomonas syringae remodels host 
chloroplasts and suppresses defenses. Curr Biol 17:499-508. https://doi.org/ 10.1016/j.cub.2007.02.028

Jung KH, Gho HJ, Giong HK et al (2013) Genome-wide identification and analysis of japonica and Indica cultivar-preferred transcripts in rice using 983 Affymetrix array data. Rice (N Y) 6(1):19. https://doi.org/10.1186/1939-8433-619

Kawahara Y, de la Bastide M, Hamilton JP, Kanamori H, McCombie WR, Ouyang S, Schwartz DC, Tanaka T, Wu J, Zhou S, Childs KL, Davidson RM, Lin H, Quesada-Ocampo L, Vaillancourt B, Sakai H, Lee SS, Kim J, Numa H, Itoh T, Buell CR, Matsumoto T (2013) Improvement of the Oryza sativa Nipponbare reference genome using next generation sequence and optical map data. Rice 6:4. https://doi.org/10.1186/1939-8433-6-4

Li B, Dewey CN (2011) RSEP: accurate transcript quantification from RNA-Seq data with or without a reference genome. BMC Bioinform 12:323. https://doi.org/ 10.1186/1471-2105-12-323

Li G, Froehlich JE, Elowsky C, Msanne J, Ostosh AC, Zhang CH, Awada T, Alfano JR (2014a) Distinct Pseudomonas type-III effectors use a cleavable transit peptide to target chloroplasts. Plant J 77:310-321. https://doi.org/10.1111/tpj. 12396

Li H, Handsaker B, Wysoker A, Fennell T, Ruan J, Homer N, Marth G, Abecasis G, Durbin R (2009a) The sequence alignment/map format and SAMtools. Bioinformatics 25:2078-2079. https://doi.org/10.1093/bioinformatics/btp352

Li M, Ma XQ, Chiang YH, Yadeta KA, Ding PF, Dong LS, Zhao Y, Li XM, Yu YF, Zhang L, Shen QH, Xia B, Coaker G, Liu D, Zhou JM (2014b) Proline isomerization of the immune receptor-interacting protein RIN 4 by a cyclophilin inhibits effector-triggered immunity in Arabidopsis. Cell Host Microbe 16:473-483. https://doi.org/10.1016/j.chom.2014.09.007

Li W, Wang BH, Wu J, Lu GD, Hu Y, Zhang X, Zhang ZG, Zhao Q, Feng Q, Zhang HY, Wang ZY, Wang GL, Han B, Wang ZH, Zhou B (2009b) The Magnaorthe oryzae avirulence gene AvrPiz-t encodes a predicted secreted protein that triggers the immunity in rice mediated by the blast resistance gene Piz-t. Mol Plant Microbe Interact 22:411-420. https://doi.org/10.1094/MPMI-22-40411

Licausi F, Ohme-Takagi M, Perata P (2013) APETALA2/ethylene responsive factor (AP2/ERF) transcription factors: mediators of stress responses and developmental programs. New Phytol 199:639-649. https://doi.org/10.1111/ nph.12291

Liu Y, Lan X, Song S, Yin L, Dry IB, Qu J, Xiang J, Lu J (2018) In planta functional analysis and subcellular localization of the oomycete pathogen Plasmopara viticola candidate RXLR effector repertoire. Front. Plant Sci 9:286. https://doi. org/10.3389/fpls.2018.00286

Mackill DJ, Bonman JM (1992) Inheritance of blast resistance in near-isogenic lines of rice. Phytopathology 82:746-749. https://doi.org/10.1094/phyto-82746

Monné M, Minier DV, Obata T, Daddabbo L, Palmieri L, Vozza A, Nicolardi C, Fernie AR, Palmieri F (2015) Functional characterization and organ distribution of three mitochondrial ATP-mg/pi carriers in Arabidopsis thaliana. Biochim. Biophys. Acta 1847:1220-1230. https://doi.org/10.1016/j. bbabio.2015.06.015

Nomura H, Komori T, Uemura S, Kanda Y, Shimotani K, Nakai K, Furuichi T, Takebayashi K, Sugimoto T, Sano S, Suwastika IN, Fukusaki E, Yoshioka $H$, Nakahira Y, Shiina T (2012) Chloroplast-mediated activation of plant immune signalling in Arabidopsis. Nat Commun 3:926. https://doi.org/10.1038/ ncomms1926

Okuyama Y, Kanzaki H, Abe A, Yoshida K, Tamiru M, Saitoh H, Fujibe T, Matsumura H, Shenton M, Galam DC, Undan J, Ito A, Sone T, Terauchi R (2011) A multifaceted genomics approach allows the isolation of the rice Piablast resistance gene consisting of two adjacent NBS-LRR protein genes. Plant J 66:467-479. https://doi.org/10.1111/j.1365-313X.2011.04502.x

Onaga G, Wydra K, Koopmann B, Chebotarov D, Séré Y, Von TieDEPann A (2017) High temperature effects on Pi54 conferred resistance to Magnaporthe oryzae in two genetic backgrounds of Oryza sativa. J Plant Physiol 212:80-93. https://doi.org/10.1016/j.jplph.2017.02.004

Park CH, Chen S, Shirsekar G, Zhou B, Khang CH, Songkumarn P, Afzal AJ, Ning YS, Wang RY, Bellizzi M, Valent B, Wang GL (2012) The M. oryzae effector AvrPiz-t targets the RING E3 ubiquitin ligase APIP6 to suppress pathogenassociated molecular pattern-triggered immunity in rice. Plant Cell 24:47484762. https://doi.org/10.1105/tpc.112.105429

Park CH, Shirsekar G, Bellizzi M, Chen SB, Songkumarn P, Xie X, Shi XT, Ning YS, Zhou B, Suttiviriya P, Wang M, Umemura K, Wang GL (2016) The E3 ligase
APIP10 connects the effector AvrPiz-t to the NLR receptor Piz-t in rice. PLoS Pathog 12:e1005529. https://doi.org/10.1371/journal.ppat.1005529

Petre B, Lorrain C, Saunders DG, Win J, Sklenar J, Duplessis S, Kamoun S (2016) Rust fungal effectors mimic host transit peptides to translocate into chloroplasts. Cell Microbiol 18:453-465. https://doi.org/10.1111/cmi.12530

Ponciano G, Yoshikawa M, Lee JL, Ronald PC, Whalen MC (2006) Pathogenesisrelated gene expression in rice is correlated with developmentally controlled Xa21-mediated resistance against Xanthomonas oryzae pv Oryzae. Physiol Mol Plant Pathol 69:131-139. https://doi.org/10.1016/j.pmpp.2007.03.002

Qu S, Liu G, Zhou B, Bellizzi M, Zeng L, Dai L, Han B, Wang GL (2006) The broadspectrum blast resistance gene Pi9 encodes a nucleotide-binding siteleucine-rich repeat protein and is a member of a multigene family in rice. Genetics 172:1901-1914. https://doi.org/10.1534/genetics.105.044891

Ramamoorthy R, Jiang SY, Kumar N, Venkatesh PN, Ramachandran S (2008) A comprehensive transcriptional profiling of the WRKY gene family in rice under various abiotic and phytohormone treatments. Plant Cell Physiol 49: 865-879. https://doi.org/10.1093/pcp/pcn061

Rodriguez-Herva JJ, Gonzalez-Melendi P, Cuartas-Lanza R, Antunez-Lamas M, RioAlvarez I, Li ZD, López-Torrejón G, Díaz I, del Pozo JC, Chakravarthy S, Collmer A, Rodríguez-Palenzuela P, López-Solanilla E (2012) A bacterial cysteine protease effector protein interferes with photosynthesis to suppress plant innate immune responses. Cell. Microbiol 14:669-681. https://doi.org/10. $1111 / j .1462-5822.2012 .01749 . x$

Rosas-Diaz T, Zhang D, Fan PF, Wang LP, Ding X, Jiang YL, Jimenez-Gongora T, Medina-Puche L, Zhao XY, Feng ZY, Zhang GP, Liu XK, Bejarano ER, Tan L, Zhang H, Zhu JK, Xing WM, Faulkner C, Nagawa S, Lozano-Duran R (2018) A virus-targeted plant receptor-like kinase promotes cell-to-cell spread of RNAi. Proc Natl Acad Sci USA 115:1388-1393. https://doi.org/10.1073/pnas. 1715556115

Seol YJ, Won SY, Shin Y et al (2016) A multilayered screening method for the identification of regulatory genes in Rice by agronomic traits. Evol Bioinforma 12:253-262. https://doi.org/10.4137/EBO.S40622

Sowden RG, Watson SJ, Jarvis P (2018) The role of chloroplasts in plant pathology. Essays Biochem 62:21-39. https://doi.org/10.1042/EBC20170020

Tang MZ, Ning YS, Shu XL, Dong B, Zhang HY, Wu DX, Wang H, Wang GL, Zhou B (2017) The Nup98 homolog APIP12 targeted by the effector AvrPiz-t is involved in rice basal resistance against Magnaporthe oryzae. Rice 10:5. https://doi.org/10.1186/s12284-017-0144-7

Tian DG, Lin Y, Chen ZQ, Chen ZJ, Yang F, Wang F, Wang ZH, Wang M (2020) Exploring the distribution of blast resistance alleles at the Pi2/9 locus in major rice-producing areas of China by a novel indel marker. Plant Dis. https://doi.org/10.1094/PDIS-10-19-2187-RE

Tian DG, Yang LM, Chen ZJ, Chen ZQ, Wang F, Zhou YC, Chen SB (2018) Proteomic analysis of the defense response to Magnaporthe oryzae in rice harboring the blast resistance gene Piz-t. Rice 1:47. https://doi.org/10.1186/ s12284-018-0240-3

Wang L, Zhao L, Zhang X, Zhang QJ, Jia YX, Wang G, Li SM, Tian DC, Li WH, Yang SH (2019) Large-scale identification and functional analysis of NLR genes in blast resistance in the Tetep rice genome sequence. Proc. Nat Acad Sci USA 116:18479-18487. https://doi.org/10.1073/pnas.1910229116

Wang R, Ning Y, Shi X, He F, Zhang C, Fan J, Jiang N, Zhang Y, Zhang T, Hu Y, Bellizzi M, Wang GL (2016) Immunity to Rice Blast Disease by Suppression of Effector-Triggered Necrosis. Curr Biol 26(18):2399-2411. https://doi.org/10. 1016/j.cub.2016.06.072

Wang XY, Jia MH, Ghai P, Lee FN, Jia YL (2015) Genome-wide association of rice blast disease resistance and yield-related components of rice. MPMI 28:13831392. https://doi.org/10.1094/MPMI-06-15-0131-R

Wang Y, Kwon SJ, Wu J, Choi J, Lee YH, Agrawal GK, Tamogami S, Rakwal R, Park SR, Kim BG, Jung KH, Kang KY, Kim SG, Kim ST (2014) Transcriptome analysis of early responsive genes in rice during Magnaporthe oryzae infection. Plant Pathol J 30:343-354. https://doi.org/10.5423/PPJ.OA.06.2014.0055

Wei T, Ou B, Li JB, Zhao Y, Guo DS, Zhu YY, Chen ZL, Gu HY, Li CY, Qin GJ, Qu LJ (2013) Transcriptional profiling of rice early response to Magnaporthe oryzae identified OsWRKYs as important regulators in rice blast resistance. PLoS One 8:e59720. https://doi.org/10.1371/journal.pone.0059720

Wilson RA, Talbot NJ (2009) Under pressure: investigating the biology of plant infection by Magnaporthe oryzae. Nat Rev Microbiol 7:185-195. https://doi. org/10.1038/nrmicro2032

Wu CH, Abd-El-Haliem A, Bozkurt TO, Belhaj K, Terauchi R, Vossen JK, Kamoun S (2017) NLR network mediates immunity to diverse plant pathogens. Proc 
Natl AcaDEPy Sci 114(30):8113-8118. https://doi.org/10.1073/pnas, 1702041114

Wu KJ, Xu T, Guo CJ, Zhang XH, Yang SH (2012) Heterogeneous evolutionary rates of Pi2/9 homologs in rice. BMC Genet 13:73. https://doi.org/10.1186/ 1471-2156-13-73

Xiao N, Wu YY, Li AH (2020) Strategy for use of rice blast resistance genes in rice molecular breeding. Rice Sci 27:263-277. https://doi.org/10.1016/.jsci.2020.05.003

Yeung KY, Ruzzo WL (2001) Principal component analysis for clustering gene expression data. Bioinformatics 17:763-774. https://doi.org/10.1093/ bioinformatics/17.9.763

Yokotani N, Tsuchida-Mayama T, Ichikawa H, Mitsuda N, Ohme-Takagi M, Kaku H et al (2014) OsNAC111, a blast disease-responsive transcription factor in rice, positively regulates the expression of defense-related genes. Mol PlantMicrobe Interact 27:1027-1034. https://doi.org/10.1094/MPMI-03-14-0065-R

Yoo YH, Kumar NA, Park JC, Lee SW, Jung KH (2017) Global analysis of differentially expressed genes between japonica and indica rice roots reveals the molecular basis for enhanced cold tolerance in japonic a rice. Plant Biotechnol Rep 11:461-473. https://doi.org/10.1007/s11816-017-0466-3

Zhang $C Y$, Fang $H$, Shi XT, He F, Wang R, Fan JB, Bai PF, Wang JY, Park CH, Bellizzi M, Zhou XP, Wang GL, Ning YS (2020) A fungal effector and a rice NLR protein have antagonistic effects on a bowman-birk trypsin inhibitor. Plant Biotechnol J. https://doi.org/10.1111/pbi.13400

Zhang XR, Garreton V, Chua NH (2005) The AIP2 E3 ligase acts as a novel negative regulator of $A B A$ signaling by promoting $A B \mid 3$ degradation. Genes Dev 19:1532-1543. https://doi.org/10.1101/gad.1318705

Zhang Y, Zhao JH, Li YL, Yuan Z, He HY, Yang HH, Ou HY, Ma CY, Ou SH (2016) Transcriptome analysis highlights defense and signaling pathways mediated by rice pi21 gene with partial resistance to M. oryzae. Front Plant Sci 7:1834. https://doi.org/10.3389/fpls.2016.01834

Zhao H, Wang X, Jia Y, Minkenberg B, Wheatley M, Fan J, Jia M, Famoso A, Edwards J, Wamishe Y, Valent B, Wang G, Yang Y (2018) The rice blast resistance gene Ptr encodes an atypical protein required for broad-spectrum disease resistance. Nat Commun 9:2039. https://doi.org/10.1038/s41467-01804369-4

Zheng XG, Chen L, Lou QJ, Xia H, Li MS, Luo L (2014) Changes in DNA methylation pattern at two seedling stages in water saving and droughtresistant rice variety after drought stress domestication. Rice Sci 21:262-270 https://doi.org/10.1016/S1672-6308(13)60194-8

Zhou B, Qu S, Liu G, Dolan M, Sakai H, Lu G et al (2006) The eight amino-acid differences within three leucine rich repeats between Pi2 and Piz-t resistance proteins determine the resistance specificity to Magnaporthe grisea. Mol Plant-Microbe Interact 19:1216-1228. https://doi.org/10.1094/MPMI-19-1216

\section{Publisher's Note}

Springer Nature remains neutral with regard to jurisdictional claims in published maps and institutional affiliations.

\section{Submit your manuscript to a SpringerOpen ${ }^{\circ}$ journal and benefit from:}

- Convenient online submission

- Rigorous peer review

- Open access: articles freely available online

- High visibility within the field

- Retaining the copyright to your article

Submit your next manuscript at $\boldsymbol{\nabla}$ springeropen.com 